\title{
SOIL DEGRADATION PROCESSES FROM POLLUTION
}

\author{
Popov Leonid*, Ciudin Gheorghe, Rotaru Serghei \\ Institute of Pedology, Agrochemistry and Soil Protection "Nicolae Dimo", \\ Academy of Sciences, Republic of Moldova \\ E-mail:leonid_popov@yahoo.co.uk \\ E-mail: rotaru_s_s87@yahoo.com
}

\begin{abstract}
The Republic of Moldova is endowed with fertile soils. Soil pollution is a major concern since no effective treatment method exists to restore the natural qualities of the soils. Polluted soil can only be rehabilitated under the long-lasting influence of natural factors.A major source of anthropic impact on soils is the application of fertilizers and pesticides in agriculture. At the same time, manure and livestock excreta often are transported to communal dump sites, where they are mixed with other wastes, or are left in ravines, along the local roads and in other unauthorized places. Instead of improving the soil productivity the nutrients find their way to and pollute the surface and ground waters. At the same time, pollution of the soils in the vicinity of former pesticide storehouses remains a problem. More than 200 storehouses have been dismantled during the last years and some of the remaining are in a poor condition, unfenced, unguarded, without doors and windows, thus being sources of chemical pollution. Moldovan soils are prone to erosion and this is how agrichemicals can travel to the water environment thus endangering water life and limiting water uses. Investigations found HCH and DDT residuals in bottom sediments from several reservoirs and lakes as well as the main rivers, Nistru and Prut (concentrations ranged between 0.2 and $15.8 \mathrm{ppb}$ ). The concentration of PCBs in the topsoil collected beneath the capacitors battery at the Vulcănesti substation reached a level of 7100 ppm which is exceeding the MAC by five orders of magnitude (!). With no exception, allowable concentrations of PCBs in soil were exceeded also on the territory of other investigated substations, with peaks registered at the Briceni substation $(2545 \mathrm{ppm})$ and the Orhei substation (1959 ppm). The degradation of soils implies the reduction or total loss of their biologic or economic productivity caused by anthropic or natural processes.
\end{abstract}

Keywords: soil degradation, erosion, contamination

Moldova is the world country that prossesses the most fertile soils - chernozems that occupy $75 \%$ of its area. But extensive soils' use led to intensive degradation of the ecological functions: energetic, biogheochemical, hidrological, gas-atmospheric, geological etc.

First of all, ecological territorial balance was disturbed. In the whole of the country, natural ecosystems (wood plantations, including forest shelter belts meadow, grassland, swamps and water systems) quota makes just $19 \%$ and at some village it falls until $7 \%$ of total territory's woodiness makes only $9,6 \%$ and at some regions falls to $1,0 \%$. At the same time, agricultural lands' cultivation level has increased and rose up to $70 \%$ in average, while in some villages exceeding $90 \%$.

The actual state of cultivated soil is no less alarming. Negative processes, which lead to soils' degradation and destruction, increase together with exploitation intensification. Soils' structure's damage, increasing compactable degree, dehumification, erosion, hydromorphism, lend slide processes, pollution are developing more intensely. Intense cultivation led to ploughing layer's natural structure's destruction, which worsened water and air penetrability along with other physical characteristics of soil. In consequences of applied tractors and other agrotechnique increasing weight a systematic increase of soil's density is observed. Moldova's chernozems and wood soils are shrinking and litterarum, which is also a negative influence on their characteristics.

Energetic function, reviewed as soil humus potential, plays an important role in soils' ecological function system, which is important not only for Moldova, but also for the other countries, where other energy source are limited. In early 60s Moldova's soils contained nearly 1 milliard ton of humus on the whole area in 1 meter layer, now it has $0,8-0,9$ milliard ton. Two thirds of this huge loss in ecologically useless, because of erosion.

Water erosion in Molodva's condition is the most than wide-spread soil-destructing process. Averagely and strongly washed-off soils make more than 275 thousands of hectares. It should be noted that the more eroded soils is, the easier it is exposed to further washing off, because lower horizons have less anti-erosion resistance. Erosion processes intensity has particularly increased in last years as a consequence of wood protection belts' destruction, implementation of so-called intra-farm crops rotation, row crops' quota increasing in cultivated areas structure and their cultivation by industrial technologies. Applying herbicides to fight weeds excludes cultivation and also excludes possibility to realize appropriate agrotechnical anti-erosion measures: slitting, discrete furrowing, chiseling, and hollowing.

Erosion processes intensity on deep-ploughed soils has increased sharply because transitional chernozems horizons appear on the surface - less humified, with worse structure, water penetrability, and low anti-erosion resistance. Erosion processes are the reason of republic's annual losses of 50 thousands tones of winter grain crops, 100 thousands tones of maize, 25 thousands tones of sunflower seeds, 150 thousands tones of sugar beet. It was calculated that if we 
take a full-profiled chernozems potential as 100, than weak wash- off one will have 75, averagely wash-off one - 60-65, strongly wash-off one - 34. Erosion completely disturbs soils" potential energy's accumulation process.

Thanks to their biogeochemical function, chernozems have accumulated in their profile carbon in organic form, nitrogen, phosphorus, some microelements. Every 100 ton erosion caused humus losses mean that also losing 5-6 tons of nitrogen, irretrievably almost half of phosphorus (which is the most scarce biofile in the world) quota, the low Clarke elements (manganese, boron, cuprum, zinc, molybdenum etc). In eroded chernozems these substances' losses make 25$75 \%$ from their initial proportion.

Moldova's soils fertility has decreased in half during the century; consequently cultures yield is decreasing accordingly.

In present for soils fertility restoration agrochemists recommend introducing 10-12 tons of manure in soil per hectare or 18-20 million of tons yearly.

Chernozems hydrological function operates with liquid effluent and solid elution. Liquid effluents may be powerful enough to cause erosion drought, and solid elution sharply disperses soils status as bio-inert carcass body. Soil's biota suffers severely too- the quantity of invertebrate, bacteria, fungi, their activity and specific diversity is reduced in 2-4 times, so on every part of washed-off chernozems the quantity of living beings is reduced, like a fragment of biosphere is dying.

The prognosis is quite imposing - all eroded agricultural lands will increase in area, and their growth in last decade makes more than $30 \%$ (tables 1-2).

Table 1

Eroded agricultural lands by zones in Repulic of Moldova'on 1.01.2002

\begin{tabular}{|c|c|c|c|c|c|c|c|c|c|c|c|}
\hline \multirow{3}{*}{ Zones } & \multirow{3}{*}{$\begin{array}{c}\text { Total } \\
\text { area, } \\
\text { hectares }\end{array}$} & \multicolumn{10}{|c|}{ Eroded soils: } \\
\hline & & \multicolumn{2}{|c|}{ total } & \multicolumn{2}{|c|}{ weakly- } & \multicolumn{2}{|c|}{ averagely- } & \multicolumn{2}{|c|}{ strongly- } & \multicolumn{2}{|c|}{$\begin{array}{c}\text { averagely-+ } \\
\text { strongly - }\end{array}$} \\
\hline & & ha & $\%$ & ha & $\%$ & ha & $\%$ & ha & $\%$ & ha & $\%$ \\
\hline Northern & 875176 & 296685 & 34,0 & 194340 & 22,2 & 73515 & 8,4 & 28881 & 3,4 & 102396 & 11,8 \\
\hline Central & 696345 & 314748 & 45,2 & 165730 & 23,8 & 102363 & 14,7 & 46655 & 6,7 & 149018 & 21,4 \\
\hline Southern & 732411 & 285640 & 39,0 & 157468 & 21,5 & 91551 & 12,5 & 36621 & 5,0 & 128172 & 17,5 \\
\hline $\begin{array}{l}\text { South- } \\
\text { Eastern }\end{array}$ & 234753 & 51880 & 22,1 & 36152 & 15,4 & 12442 & 5,3 & 3287 & 1,4 & 15729 & 6,7 \\
\hline Total & 2538685 & 949468 & 37,4 & 553433 & 21,8 & 279255 & 11,0 & 116780 & 4,6 & 396035 & 15,6 \\
\hline \multicolumn{12}{|c|}{ Referring to } \\
\hline Right bank & 2274453 & 889481 & 39,1 & 511238 & 22,5 & 265486 & 11,7 & 112756 & 5,0 & 378242 & 16,7 \\
\hline Left bank & 264232 & 59987 & 22,7 & 42195 & 16,0 & 13769 & 5,2 & 4024 & 1,5 & 17793 & 6,7 \\
\hline
\end{tabular}

Table 2

Plough soils' wash-off level on the slope with different steepness in 2001

\begin{tabular}{|c|c|c|c|c|c|c|c|c|c|}
\hline \multirow{3}{*}{ Zones } & \multirow{2}{*}{ Total } & \multicolumn{8}{|c|}{ Washed-off soils } \\
\hline & & \multicolumn{2}{|l|}{ Total: } & \multicolumn{2}{|c|}{ weakly- } & \multicolumn{2}{|c|}{ averagely- } & \multicolumn{2}{|c|}{ strongly } \\
\hline & $\begin{array}{c}\text { Thousands } \\
\text { hectares }\end{array}$ & $\begin{array}{c}\text { Thousands } \\
\text { hectares }\end{array}$ & $\%$ & $\begin{array}{c}\text { Thousands } \\
\text { hectares } \\
\end{array}$ & $\%$ & $\begin{array}{c}\text { Thousands } \\
\text { hectares }\end{array}$ & $\%$ & $\begin{array}{c}\text { Thousands } \\
\text { hectares }\end{array}$ & $\%$ \\
\hline \multicolumn{10}{|c|}{ Total on slope with steepness $>1^{\circ}$} \\
\hline Northern & 596,5 & 226,7 & 38.0 & 148,4 & 24,9 & 56,2 & 9,4 & 22,1 & 3,7 \\
\hline Central & 374,7 & 208,8 & 55,7 & 109,9 & 29,3 & 67,9 & 18,1 & 31,0 & 8,3 \\
\hline Southern & 397,0 & 201,7 & 50,8 & 111,2 & 28,0 & 64,7 & 16,3 & 25,8 & 6,5 \\
\hline South-Eastern & 98,2 & 42,5 & 43,3 & 29,6 & 30,1 & 10,2 & 10,4 & 2,7 & 2.8 \\
\hline Total & 1466,5 & 679,7 & 46,3 & 399,1 & 27,2 & 199,0 & 13,6 & 81,6 & 5,6 \\
\hline \multicolumn{10}{|c|}{ Total on slope with steepness $1-5^{\circ}$} \\
\hline Northern & 482,1 & 112,4 & 23,3 & 112,4 & 23,3 & - & - & - & \\
\hline Central & 232.8 & 67,0 & 28,8 & 67,0 & 28,8 & - & - & - & \\
\hline Southern & 293,1 & 97,8 & 33,4 & 97,8 & 33.4 & - & - & - & \\
\hline South-Eastem & 85,3 & 29,6 & 34,7 & 29,6 & 34,7 & - & - & - & \\
\hline Total & 1093,3 & 306.8 & 28.1 & 306.8 & 28.1 & - & - & - & - \\
\hline
\end{tabular}




\begin{tabular}{|l|c|c|c|c|c|c|c|c|c|}
\hline \multicolumn{10}{|c|}{ Total on slope with steepness 5-8 } \\
\hline Northern & 89,6 & 89,6 & 100 & 36,0 & 40,2 & 53,6 & 59,8 & - & - \\
\hline Central & 104,4 & 104,4 & 100 & 42,9 & 42,1 & 61,5 & 58,9 & - & - \\
\hline Southern & 80,6 & 80,6 & 100 & 13,4 & 16,6 & 64,7 & 80,3 & 2,5 & 3,1 \\
\hline South-Eastern & 11,0 & 11,0 & 100 & - & - & 10,2 & 92,7 & 0,8 & 7,3 \\
\hline Total & $\mathbf{2 8 5 , 6}$ & $\mathbf{2 8 5 , 6}$ & $\mathbf{1 0 0}$ & $\mathbf{9 2 , 3}$ & $\mathbf{3 2 , 3}$ & $\mathbf{1 9 0 , 0}$ & $\mathbf{6 6 , 5}$ & $\mathbf{3 , 3}$ & $\mathbf{1 , 2}$ \\
\hline \multicolumn{8}{|c|}{ Total on slope with steepness $>\mathbf{8}^{\circ}$} \\
\hline Northern & 24,7 & 24,7 & 100 & - & - & 2,6 & 10,5 & 22,1 & 89,5 \\
\hline Central & 37,4 & 37,4 & 100 & - & - & 6,4 & 17,1 & 31,0 & 82,9 \\
\hline Southern & 23,3 & 23,3 & 100 & - & - & - & - & 23,3 & 100,0 \\
\hline South-Eastern & 1,9 & 1,9 & 100 & - & - & - & - & 1,9 & 100,0 \\
\hline Total & $\mathbf{8 7 , 3}$ & $\mathbf{8 7 , 3}$ & $\mathbf{1 0 0}$ & - & - & $\mathbf{9 , 0}$ & $\mathbf{1 0 , 3}$ & $\mathbf{7 8 , 3}$ & $\mathbf{8 9 , 7}$ \\
\hline
\end{tabular}

Downhill and strongly wash-off lands ploughing is observed in 2001 in Stefan-voda, Anenii Noi and other regions. Chernozems' erosion should be minimized. Agronomic views on soils' erosion must give up to a more biosphereoriented and ecological view, as 1251.8 thousands of people became proprietors of more than 2 millions of hidelands at the end of 2000. While parting up land into hidelands, anti-erosion requirements of farm's territory organizing were not met, hidelands are often allotted along the hills, which significantly impedes implementation of anti-erosion measures to maintain soil cover.

In sum, erosion not only damages soil, but biosphere in whole, brings on negative social and demographic consequences.

Several measures - organization, agrotechnical, hydrotechnical, phytomeliorative and others should be taken in order to prevent Moldova's soils' ecological functions degradation. Their implementation should be complete, and not fragmented.

One of the first conditions is to change correlation between natural and anthropogenic, transformed landscapes in different regions. Ecological balance is off the question in conditions of complete lack of forests and natural gramineous vegetation in Belti Steppe and Southern Region. Consequently, there's a strong need in wood planting, hills tufting, flood plains, hollows, runnels, swamps and others natural destination's restoration. It is necessary to examine Moldova's flood plains' soils and to evaluate them.

The other condition is to create natural carcass, a green skeleton - protection belts situated on watersheds. They would serve to smooth climatic conditions; lessen wind's force and storms' destructive power. Anti-erosion, flowregulating belts are strictly necessary in order to regulate surface flow on hills. These belts should be connected with areas of natural forests and wood plantings, created on ravine's and landslide's hills, with areas where natural gramineous vegetation is still preserved, and with protection zones along rivers and lakes. Natural carcass will provide a possibility to cultivate soil and plant cultures across the hills and by horizontals, to implement agrotechnical and anti-erosion measures. It would benefit to preserve local flora and fauna genetic fund.

The areas with mainly distribution of averagely and strongly washed-off soils should be taken out of ploughing fund and intense use; because they practically cannot be protected from erosion while being a part of crops rotation. These soils should be tufted and planted with multiyear herbs. Natural vegetation restoration in rivers' flood plains, cavins and hollows would regulate flow and clean surface waters. Thus, a considerable balance between natural and anthropogenic components of ecosystems will be created and chernozems' ecological functions will be preserved.

The problem of soils radioactive pollution becomes more and more actual and serious.

The application of radio nuclides, particularly $\mathrm{Cs}^{137}$, for water erosion and sedimentation studies in Republic of Moldova has not been attempted so far. Consequently the investigations were made on reservoir sedimentation rates in an area subjected to wide range of land degradation by sheet-rill erosion.

The profile characteristics support the assumption that in most undisturbed sites there is a sharp decline in $\mathrm{Cs}^{137}$ activity along with increasing depth. Such an asymmetrical distribution of the $\mathrm{Cs}^{137}$ would suggest a standard pattern in the form of a cantilever. If the validity of this assumption is accepted it is possible to define two major types of $\mathrm{Cs}^{137}$ cantilever distribution: shallow and deep buried cantilever.

The main criterion in classifying these patterns lies generally in the shape of $\mathrm{Cs}^{137}$ depth profile and particularly in burial magnitude of $\mathrm{Cs}^{137}$ peak derived from Chernobyl.

Hills area has been impacted by greatest sedimentation. This regional differentiation is consistent with the decrease in clay and increase in sand content of substratum layers as moving from the North to the South.

Accumulation of ${ }^{\mathrm{Cs} 137}$ in reservoirs in the Republic of Moldova is mainly associated with the Chernobyl imputes and subsequently with $\mathrm{Cs}^{137}$ derived from testing of nuclear weapons.

The pattern of shallow buried cantilever typifies those areas where $\mathrm{Cs}^{137}$ peak concentration exhibits in the upper part of the profile commonly at a depth $15-50 \mathrm{~cm}$ ( a plant's main roots inhabited layer), especially in the northern and 
southern part of Moldova, where rill - inter-rill erosion is the main sediment source.

Along with radioactive pollution, there's equally actual problem of waste pollution of soil. Around the localities by different ways, soil is polluted with solid waste. Even more dangerous consequences may have chemical pollution. Sulphur and nitrogen oxides diffuse through atmosphere, deposit on soil and in due course change its initial physical composition. Heavy metals get into soil together with wastewaters and their sediments (mercury, zinc, cuprum etc), from automobiles' exhaust gases (lead). Soils' chemical pollution takes larger scale together with agriculture's chemicalization increase. Ballast elements (fluorine, chlorine) are applied together with fertilizers, different elements which are non-characteristic for soil are introduced while spray treatment for diseases and pest control and particularly while introducing herbicides. As the areas of irrigated lands are widening, we may observe the increase in threat and processes' manifestation scales of gleyification, secondary water clogging, irrigational erosion, sodisation and salinization, particularly when alkaline and mineralized waters are used for irrigation.

That's why the state of land resources is stressed, and the state of soil cover is alarming. Systematic control over its usage is needed and in some special cases there's a need to take immediate action.

Apart from using soil, humankind has no other possibility to obtain food products and numerous materials necessary for existence. Soil as a source of material values, as a priceless natural wealth and the main environmental component must function perfectly and serve forever to us and our future generations.

\section{References:}

[1]. Boaghe Lilia,; Stasiev Gr.; Chiriliuc V. Pierderile pedoerozionale de microelemente prin scurgeri solide si lichide, Rev. "Mediul Ambiant", nr. 3(57), 2011, p. 17-22

[2]. Republic of Moldova State of the environment report, Chisinau. S.n., 2007, p. 61-64

[3]. Кирилюк В.П. Микроэлементы в компонентах биосферы Молдовы: Кишинев, 2006, с. 70-82 